\title{
Pathohistological Study of Synovium in Idiopathic Carpal Tunnel Syndrome with Tenosynovitis
}

\author{
by \\ Akihiko Asami, Keizo Morisawa, Hiroko Mine \\ and Hideo Watanabe \\ Department of Orthopaedic Surgery, \\ Saga Medical School, Saga, Japan \\ Toshiyuki Tsuruta \\ Department of Orthopaedic Surgery, \\ Social Insurance Saga Hospital, Saga, Japan
}

\begin{abstract}
Forty five patients (66 wrists) with idiopathic carpal tunnel syndrome were investigated. Of these, only 11 patients, 16 wrists $(24.2 \%)$ had had idiopathic carpal tunnel syndrome associated with tenosynovitis clinically, such as trigger finger and de Quervain's disease. Although the cause of idiopathic carpal tunnel syndrome have been regarded as chronic tenosynovitis, the prevalence of pathohistological inflammation was not so high. In this study, the ratio of advanced or severe inflammation was just only $8 \%$. This result was similar to recent pathohistological study of flexor tendon synovium. There were no significant difference between clinical tenosynovitis and pathohistological synovitis. The most important pathohistological findings were edema and fibrosis. Vascular changes including sclerotic intima and occlusion of the lumen were coexistent in some specimens $(40 \%)$. Anatomical risk factor, tenosynovitis, vascular changes and hormone imbalance were influenced each other.
\end{abstract}

Key words : idiopathic carpal tunnel syndrome (特発性手根管症候群), tenosynovitis (腱滑膜 炎), pathohistological study (病理組織学的研究), edema (浮腫), fibrosis (線維化)

\section{Introduction}

In many patients diagnosed with carpal tunnel syndrome (CTS), there is specific etiology of this disease. In idiopathic cases, chronic tenosynovitis is often proposed as the reason for increased pressure on the median nerve. The role of tenosynovitis as a cause of this syndrome has been emphasized by several authors ${ }^{299-11}$. But its pathophysiology was still not clearly understood. The link between tenosynovitis and idiopathic CTS was tenuous since recent histological studies could not demonstrate tenosynovitis in early stege of CTS. The true prevalence of tenosynovitis in the idiopathic CTS population should be high if this is the main cause of CTS. This study determined the prevalence of stenosing tenosynovitis, such as trigger finger and de Quervain's disease in a population of clinically diagnosed CTS in those cases that have not resolved with conservative treatment, and described the pathohistological findings in the flexor tendon synovium. 


\section{Materials and methods}

The patients group with CTS consisted of 45 patients (66 wrists, 8 males, 37 females) who were treated by carpal tunnel release. Patients with trauma, tumor of the median nerve, rheumatoid arthritis, other inflammatory diseases, diabetes mellitus, kidney disorder, hypothyroidism and Buerger's disease were excluded in this study. The age range at the time of surgery was from 15 to 68 years (mean 52.8 years). Prevalence of tenosynovitis associated with idiopathic CTS were investigated. In this series, synovectomy was performed in 22 patients (25 wrists). These specimens were studied pathohistologically.

\section{Results}

Eleven cases, 16 wrists $(24.2 \%$; 2 males, 9 females, $37-71$ years, mean 57.3 years $)$ of idiopathic CTS associated with tenosynovitis were summarized in Table 1 . There were 9 cases (11 wrists) of trigger finger and 2 cases (2 wrists) of de Quervain's disease, respectively.

Pathohistological findings were divided into five groups ; 1) inflammation, 2) edema, 3) fibrosis, 4) hyalinization and 5) sclerotic change or obstruction of small vessels.

1) Inflammation

The presence of inflammatory cells was a criterion considered fundamental to the definition of tenosynovitis. Inflammatory cells were found in $32 \%$ (8 cases) of the patients speciments, with infiltrations consisting almost exclusively of lymphocytes and occasional histiocytes. An advanced and diffuse inflammatory infiltration was encountered in only $2(8 \%)$ specimens (Fig. 1 ), and those of others were mild or moderate in degree (Fig. 2). Of 11 wrists which showed synovitis pathohistologically, only 3 wrists $(27.3 \%)$ had symptomatic tenosynovitis. On the other hand, 8 wrists $(72.7 \%)$ showed no tenosynovitis clinically.

\section{2) Edema}

Edema was a consistent pathohistological finding in idiopathic CTS, and was in $88 \%$ of all

Table 1 Patients lists of idiopathic carpal tunnel syndrome with tenosynovitis

\begin{tabular}{cccccl}
\hline \hline No. & Name & Sex & Age & Affected site & Tenosynovitis \\
\hline 1 & K.K. & F & 68 & Right & Rt. ring trigger finger \\
2 & S.F. & F & 57 & Left & Lt. middle trigger finger \\
3 & S.K. & F & 37 & Left & Lt. de Quervain's disease \\
4 & T.K. & F & 66 & Left & Lt. trigger thumb \\
5 & F.S. & F & 55 & Right & Rt. trigger thumb \\
6 & Y.M. & F & 65 & Right & Rt. trigger thumb \\
7 & M.T. & F & 54 & Bilateral & Rt. index, middle trigger fingers \\
& & & & & Lt. thumb, middle trigger fingers \\
8 & M.M. & M & 60 & Bilateral & Lt. do Quervain's diseaes \\
9 & H.N. & F & 45 & Bilateral & Rt. middle trigger finger \\
10 & T.N. & F & 52 & Bilateral & Rt. little trigger finger \\
11 & W.M. & M & 71 & Bilateral & Rt. middle trigger finger \\
& & & & & Lt. thumb, middle trigger fingers \\
\hline
\end{tabular}




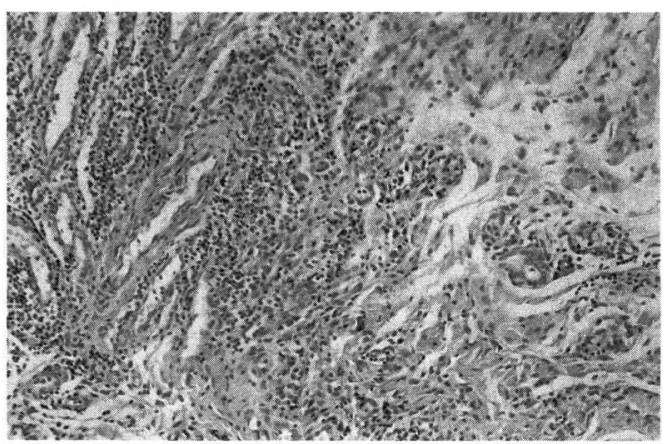

Fig. 1 An advanced and diffuse inflammatory infiltration taken from a patient with carpal tunnel syndrome. (Hematoxylin-eosin stain ; magnification $\times 100$ )

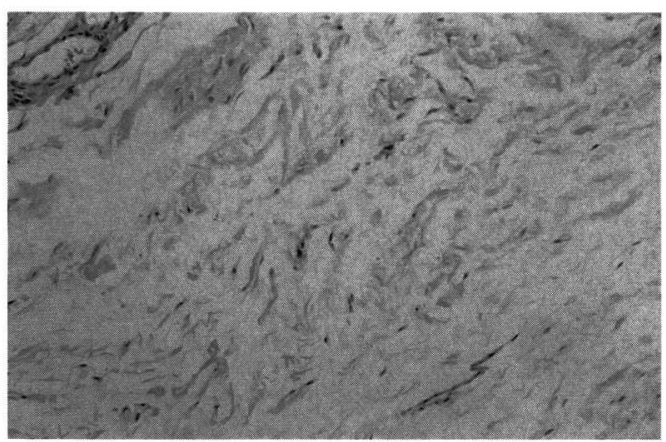

Fig. 3 The histology of the flexor synovium with edema. (Hematoxylin-eosin stain; magnification $\times 100$ )

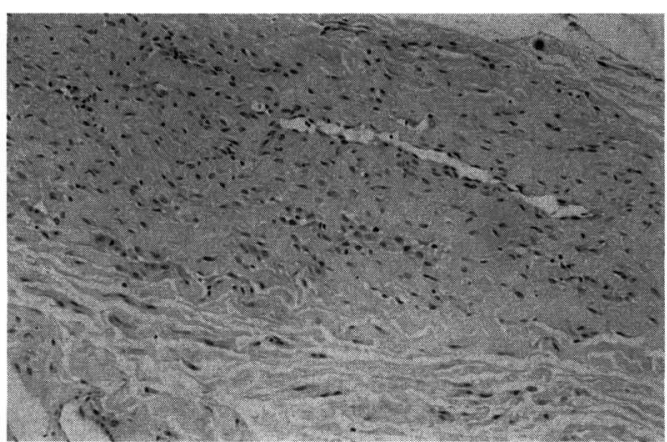

Fig. 2 Mild inflammation with infiltration consisting intermediate number of lymphocytes. (Hematoxylin-eosin stain; magnification $\times 100$ )

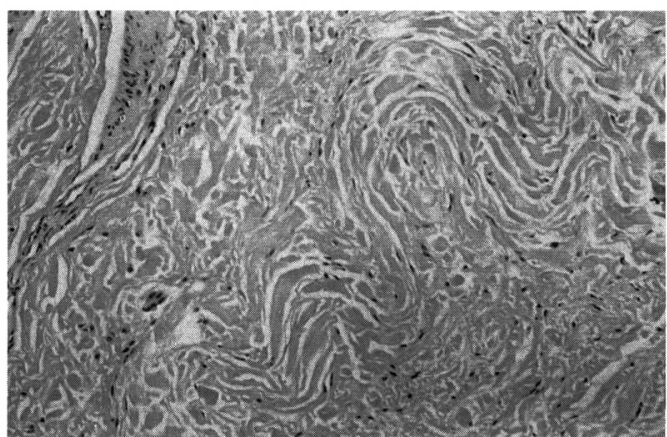

Fig. 4 Massive proliferation of the synovium with fibrosis (Hematoxylin-eosin stain; magnification $\times 100$ )

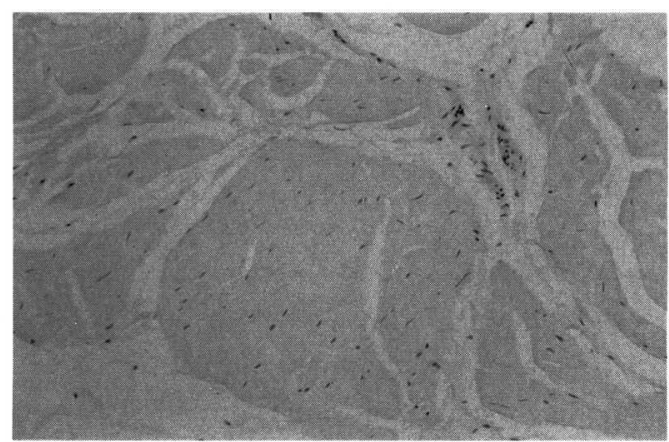

Fig. 5 Hyaline change in the synovium. (Hematoxylin-eosin stain ; magnification $\times 100$ ) 


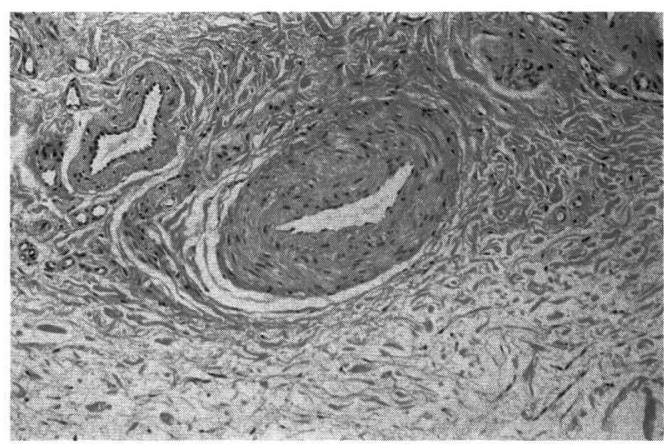

(a)

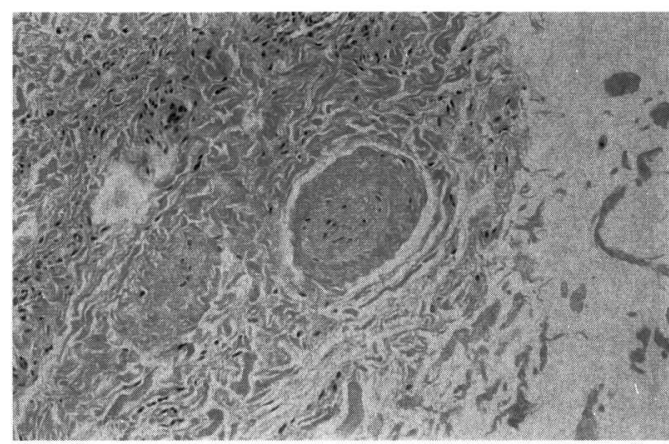

(b)

Fig. 6 Synovial small vessels with severely sclerotic intima (a) and occlusion by a platelet thrombus (b). (Hematoxylin-eosin stain;magnification $\times 100$ )

specimens (Fig. 3). In some specimens, edema was coexistent with inflammation or fibrosis.

3) Fibrosis

Fibrosis was considered as an irreversible change of connective tissue due to accerelation of carpal pressure. Fibrosis was found in $84 \%$ of all specimens (Fig. 4).

4) Hyalinization

Hyalinization was present in only 2 specimens ( $8 \%$ ) (Fig. 5).

5 ) Sclerotic change or occlusion of small vessels

Vascular changes, such as sclerotic change or occlusion of small vessels were found in $40 \%$ (Fig. 6).

\section{Discussion}

CTS without evidence of injury, anomalies of artery or muscles, rheumatoid arthritis and other inflammatory diseases, or systemic diseases (idiopathic CTS) is believed to result from a chronic nonspecific synovitis involving the flexor synovium in the carpal tunnel for a long time $^{299)-11}$. Some authors ${ }^{(2))}$ stated that jobs requiring highly repetitive and forceful sustained hand activity, such as grinders, butchers, grocery store workers, frozen food factory workers and platers were associated with an increased risk for CTS. The syndrome was most often reffered to as a result of tenosynovitis involving the flexor tendons.

But there were differences between recent pathohistological features and previous studies of the flexor tendon synovium in the idiopathic CTS. The previous studies showed high prevalence of inflammation. One of the reason was that those studies contained patients of rheumatoid arthritis. According to recent pathohistological study, inflammation was present in only $10 \%$ or less of the patient specimens s/48) $^{3 / 2133}$. In our study, obvious inflammation was in only $8 \%$, except for mild or moderate inflammation. Edema and fibrosis were observed frequently. Vascular sclerosis or occlusion were found occasionally.

Tenosynovitis is well described and most orthopedic surgeons are familiar with it. Generally, it is caused by heavy work. But it is a remarkable paradox that the complaints of it have increased in number as the physical effort required at the workplace has been reduced by labour- 
saving devices. Another paradox is that few of the compensation claims came from keyboard workers such as secretary and journalists as foundry workers or agricultural labourers, who often do heavy and repetitive work ${ }^{14)}$. In our series, there were no significant differences between pathohistological synovitis and symptomatic synovitis.

Basically, patients with CTS have anatomical risk factor. Computed tomography studies have demonstrated that the carpal tunnel is smaller in women compared with men ${ }^{11}$. The carpal tunnel has also been shown to be smaller in women with idiopathic CTS, as compared with unaffected women ${ }^{1 / 5)}$; this bony stenosis seems to be inherited rather than acquired ${ }^{155}$.

It is fact that edema and fibrosis play an important role as the cause of idiopathic CTS. Tenosynovitis due to chronic repetitive minor trauma or mechanical stress, and venous congestion due to vascular sclerosis and obstruction were influenced each other.

We concluded that the cause of idiopathic CTS is not all chronic tenosynovitis but synovial edema and fibrosis associated with anatomical risk factor, tenosynovitis, venous congestion and hormone inbalance.

\section{References}

1) Dekel, S. et al.: Idiopathic carpal tunnel syndrome caused by carpal stenosis, Br Med J., $280: 1297-1299,1980$.

2) Ditmars, D. M., Houin, H. P.: Carpal tunnel syndrome. Hand Clinics., 2:525-532, 1986.

3) Faithfull, D. K., Moir, D. H., Irekand, J.: The micropathology of the typical carpal tunnel syndrome. J Hand Surg., 11B : 131-132, 1986.

4) Fuchs, P.C., Nathan, P. A., Myera, L. D.: Synovial histology in carpal tunnel syndrome. J Hand Surg., 16A : 753$758,1991$.

5) Gelmers, H. J.: Primary carpal tunnel stenosis as a cause of entrapment of the median nerve. Acta Neurochir., 55 : 317-320, 1981.

6) Hagberg, M., Morgenstern, H., Kelsh, M.: Impact of occupations and job tasks on the prevalence of carpal tunnel syndrome. Scand J Work Environ Health., $18: 337-345,1992$.

7) Hjollund, N.H., Bonde, J. P.: Can the carpal tunnel syndrome be work-related?. Ugeskr Leager., 154 : 2968-2974, 1992.

8) Patiala, H. et al.: Carpal tunnel syndrome : anatomical and clinical investigation. Arch Orthop Trauma Surg., 104 : 69-73, 1985.

9) Phalen, G.S., Kendrick, J. I.: Compression neuropathy of the median nerve in the carpal tunnel. JAMA., 164 : 524-530, 1957.

10) Phalen, G.S.: The Carpal-tunnel syndrome. Seventeen years' experience in diagnosis and treatment of 654 hands. J Bone Joint Surg., 48A : 211-228, 1966.

11) Phalen, G.S.: The carpal tunnel syndrome. Clinical evaluation of 598 hands. Clin Orthop., $83: 29-40,1972$.

12) Scelsi, R., Zanlungo, M., Tenti, P.: Carpal tunnel syndrome. Anatomical and clinical correlations and morphological and ultrastructual aspects of the tenosynovial sheath. Ital J Orthop Traumatol., $15: 75-80,1989$.

13) Schuind, F., Ventura, M., Pasteels, J. L.: Idiopathic carpal tunnel syndrome:histological study of flexor tendon synovium. J Hand Surg., 15A : 497-503, 1990.

14) Semple, J.C.: Tenosynovitis, repetitive strain injury, cumulative trauma disorder and overuse syndrome. J Bone Joint Surg., 73B : 536-538, 1991. 
〈和文抄録〉

\title{
滑膜組織所見よりみた特発性手根管症候群の 腱滑膜炎についての検討
}

\author{
佐賀医科大学整形外科 \\ 浅 見 昭 彦·森 澤 佳 三 \\ 峯博子.渡辺 英夫 \\ 社会保険佐賀病院整形外科 \\ 鶴 田 敏 幸
}

特発性手根管症候群の原因は従来より腱滑膜炎であ るといわれているが, 明らかな腱滑膜炎はさほど多く ない. そこで, 本疾患と狭窄性腱鞘炎との因果関係, および滑膜の病理組織学的所見について検討を加えた. 特発性手根管症候群の患者 45 例, 66 手（男性 8 例, 女性 37 例, 手術時年齢 15 68 歳, 平均 52.8 歳) に ついて狭窄性腱鞘炎の有無を, また手術時, 手関節滑 膜が採取された 22 例, 25 手について病理組織所見を 検討した。

弾発指, de Quervain 病などのいわゆる狭窄性腱
鞘炎を合併していたものは 45 例中 11 例, 16 手 (24.2 \%) であった．組織所見の内訳は，炎症 $32 \%$, 浮腫 88 $\%$, 線維化 $84 \%$, 硝子質化 $8 \%$, 小血管の硬化あるい は閉塞 $40 \%$ であった。等度以上の炎症は $8 \%$ の であった。

本症の組織所見では浮腫, 線維化を示すものが大部 分であったことより, 発症要因は腱滑膜炎のみならず 様々なファクターが複雑に絡み合って発症するものと 推察された。 